\title{
Pengembangan Modul Sharaf Dengan Pendekatan Deduktif Di Pondok Modern Madinah Lampung
}

\author{
Mezan el-Khaeri Kesuma, Reni Puspita Sari
}

Fakultas Tarbiyah dan Keguruan, UIN Raden Intan Lampung

mezan@,radenintan.ac.id

\section{Received: \\ 08-06-2020 \\ Revised: \\ 16-06-2020 \\ Accepted: \\ 30-06-2020}

Article History

Keywords:

Module, Sharaf, Deductive

\begin{abstract}
:
The objectives of this study are: 1) Developing the sharaf modules with the deductive approach, 2) Knowing the feasibility of the sharaf module with a deductive approach and 3) Knowing the effectiveness of the sharaf module with the deductive approach of class X students in Pondok. Modern Madinah Labuban Maringgai, East Lampung. The development model used the Borg and Gall model with seven stages, namely: preliminary study, research planning, design development, limited trials, limited revision of trial results, wider product testing, and wider revision of trial results. Observing the above statement, the results of this study show that: development of sharaf module with deductive approach is very feasible to use, the results of the material expert validation are $89 \%$ and the learning design expert validation results are $86 \%$, the average score of the student's pretest is 54.16 and the posttest value is 84.16. Based on the results of calculations using the SPSS application 24, it is known that the value of $t_{0}=15.288$ and table 1.69913 at a significance level of $5 \%$, so it can be concluded that there is a difference between the pretest value $t$ and posttest grade $X$ students, because to $15.288>$ table $1.69913, H_{a}$ accepted and $H_{0}$ rejected
\end{abstract}

\section{Pendahuluan}

Ilmu Sharaf adalah salah satu cabang ilmu bahasa atau linguistik yang sering disebut morfologi. Oleh karena itu, ilmu shorof merupakan sebuah kajian penting yang di dalamnya menyangkut struktur bahasa. Ada beberapa pendekatan yang dapat digunakan dalam mengajarkan sharf, yaitu dengan pendekatan deduktif. Pendekatan deduktif adalah pendekatan pembelajaran sharaf yang menyajikan kaidah-kaidah terlebih dahulu kemudian contoh-contoh. ${ }^{1}$ Agar peserta didik mampu memahami dan mengaplikasikan materi sharaf, maka dibutuhkan banyak contoh serta latihan yang disajikan dalam kitab sharaf, karena tujuan dari belajar sharaf secara umum adalah mengetahui perubahan asal kata menjadi beberapa macam kata sekaligus mengetahui bagaimana perubahannya menurut pola bentuk kata serta untuk menghindari beberapa kesalahan yang berkaitan dengan problem sharaf.

${ }^{1}$ Isnainiyah, "Pengembangan Kitab Matan Al-Jurumiyah Dengan Pendekatan Induktif Untuk Siswi Madrasah Diniyah Nurul Ulum," Seminar Nasional Bahasa Arab Mahasiswa III (2019): 1-20. 
Berdasarkan hasil observasi di Pondok Modern Madinah, diketahui bahwa buku ajar yang digunakan selama ini tidak memungkinkan peserta didik belajar secara mandiri. Materi yang dimuat dalam kitab cetak kurang sistematis dan tidak banyak memuat contoh-contoh kalimat pada setiap bab serta latihan-latihan tidak sesuai dengan tujuan pembelajaran, karena Kitab tersebut tidak memuat tujuan pembelajaran yang akan dicapai oleh peserta didik. Hal tersebut dapat menyebabkan rendahnya kemampuan sharaf peserta didik, misalnya peserta didik kurang mampu membuat contoh-contoh kalimat yang di dalamnya terdapat fi'il mujarrod dan fi'il mazid dengan benar. Oleh karena itu perlu adanya bahan ajar penunjang berupa modul yang memungkinkan peserta didik belajar secara mandiri dan dapat membantu mereka untuk lebih mudah dalam memahami materi sharaf karena dalam modul terdapat banyak contoh kalimat serta latihan latihan pada setiap bab yang disesuaikan dengan tujuan pembelajaran.

Modul merupakan komponen pembelajaran yang harus dipersiapkan secara baik oleh guru. Pengembangan modul sangat penting dalam praktik pendidikan. Hal yang harus dipertimbangkan dalam pengembangan modul harus menyesuaikan tujuan dan kebutuhan peserta didik. Modul menurut Meyer yang dikutip oleh Lasmiyati adalah " a modul is relatively short self-contained independent unit of instructional designed to achieve a limited set of specific and well-defined educational objectives. It usually has a tangible format as a set or kit of coordinated and highly produced materials involving a variety of media. A module may or may not be designed for individual self paced learning and may employ a variety of teaching techniques".

Untuk memberikan pengajaran sharaf yang efektif disekolah, Salah satu kemampuan yang dimiliki oleh guru dalam melaksanakan tugasnya adalah mengembangkan buku ajar berupa modul yang sesuai dengan kebutuhan peserta didik dan karakteristiknya agar dapat menciptakan pembelajaran yang berkualitas, kondusif, bermakna dan menyenangkan. Berdasarkan hasil penelitian Mujab, tujuan dari pengajaran menggunakan modul adalah dapat memberi kesempatan bagi siswa untuk belajar sesuai dengan kecepatan dan caranya masing-masing, karena mereka mampu menggunakan beberapa teknik yang berbeda untuk menyelesaikan masalah. ${ }^{3}$ Selanjutnya hasil penelitian Sica Septyenthi, Penggunaan modul juga mampu meningkatkan motivasi, karena salah satu dari karakteristik modul yaitu self instruction yaitu menghasilkan modul yang memungkinkan seseorang belajar secara mandiri. ${ }^{4}$ Secara umum tujuan pengembangan ini adalah menghasilkan produk berupa modul shorof dengan pendekatan deduktif untuk peserta didik Pondok Modern Madinah. Adapun tujuan kajian ini secara khusus adalah mengetahui bagaimana

\footnotetext{
2 Idris Harta Lasmiyati, "Pengembangan Modul Pembelajaran Untuk Meningkatkan Pemahaman Konsep Dan Minat SMP,” Pythagoras: Jurnal pendidikan Matematika Vol 9, no. No 2 (2014): 161-174.

${ }^{3}$ Ahmad Saiful Mujab, "Pengembangan Modul Bahasa Arab Berbasis Teori Psikologi Perkembangan Remaja Elizabeth B. Hurlock Kelas X MA,” Jurnal Lisanul Arab Vol 7, no. No 1 (2018): 33-37.

${ }^{4}$ Upik Yelianti Sica Septyenthi, Aprizal Lukman, "Pengambangan Modul Pembelajaran IPA Berbasis Entrepreneurship Di SMK Negeri 2 Kota Jambi,” Jurnal Edu Sains Vol 3, no. No 2 (2014).
} 
praktikalitas, validitas dan efektifitas modul shorof dengan pendekatan deduktif untuk peserta didik Pondok Modern Madinah.

Salah satu kebutuhan peserta didik terkait modul sharaf adalah latihan-latihan yang sesuai dengan tujuan pembelajaran dan contoh-contoh kalimat pada setiap bab. Adapun Kebutuhan pendidik sebagai pengguna modul adalah adanya perluasan isi materi terkait pembahasan sharaf agar pendidik memiliki pengetahuan luas terhadap pembelajaran sharaf dan tidak hanya sekedar mengajarkan materi yang terdapat pada buku cetak.

\section{Landasan Teori}

Modul merupakan suatu paket bahan ajar yang disajikan secara sistematis sehingga pembelajar dapat belajar mandiri tanpa bimbingan seorang guru. Dengan demikian maka sebuah modul harus dapat dijadikan bahan ajar sebagai pengganti fungsi guru. Apabila guru berperan sebagai fasilitator dalam menjelaskan sesuatu maka modul harus mampu menjelaskan sesuatu dengan bahasa yang mudah dipahami peserta didik sesuai dengan tingkat pengetahuan dan usianya. $^{5}$

Menurut Asyhar yang dikutip oleh Sica Septyenthi dkk dalam jurnalnya, berpendapat bahwa modul adalah salah satu bentuk bahan ajar cetak yang disusun dan dapat digunakan oleh peserta untuk belajar secara mandiri, oleh karena itu modul dilengkapi dengan petunjuk untuk belajar sendiri dalam hal ini sehingga peserta didik dapat belajar sendiri tanpa kehadiran pengajar secara langsung. ${ }^{6}$ Sedangkan menurut Abdul Majid bahwa sebuah modul akan bermanfaat, jika peserta didik dapat menggunakannya dengan mudah. Dengan demikian konten sebuah modul harus disajikan dengan menggunakan bahasa yang baik dan menarik dan di lengkapi dengan ilustrasi serta memuat kompetensi dasar yang akan dicapai oleh peserta didik. ${ }^{7}$

Adapun Fungsi Modul dalam kegiatan pembelajaran adalah sebagai berikut: 1) Bahan ajar mandiri, penggunaan modul dapat membantu peserta didik untuk meningkatkan kemampuan mereka sesuai tingkat kecepatan dalam belajar, 2) Pengganti fungsi pendidik, modul harus menjelaskan materi pembelajaran dengan baik dan mudah dipahami oleh peserta didik sesuai tingkat pengetahuan dan usia mereka, 3) Alat evaluasi., peserta didik dituntut untuk mampu mengukur dan menilai sendiri sejauh mana tingkat penguasaannya terhadap materi yang dipelajari, 4) Bahan refrensi bagi peserta didik. Modul berisi berbagai materi yang harus dipelajari peserta didik untuk meningkatkan kemampuan yang menjadi standar kompetensi. ${ }^{8}$

\footnotetext{
${ }^{5}$ Departemen Nasional, "Pendidikan, Panduan Pengembangan Bahan Ajar" (Direktorat Pembinaan Sekolah Menengah Atas: Direktorat Jenderal Manajemen ..., 2008).

${ }^{6}$ Sica Septyenthi, Aprizal Lukman, and Upik Yelianti, "Pengembangan Modul Pembelajaran IPA Berbasis Entrepreneurship Di SMK Negeri 2 Kota Jambi," Edu-Sains: Jurnal Pendidikan Matematika dan Ilmu Pengetabuan Alam 3, no. 2 (2014).

7 Abdul Majid, "Perencanaan Pembelajaran," Bandung: PT Remaja Rosdakarya (2008).

8 Andi Prastowo, "Panduan Kreatif Membuat Bahan Ajar Inovatif” (Yogyakarta: DIVA press, 2011).
} 
Modul dikatakan baik, jika memenuhi kriteria modul. Kriteria modul yang baik adalah modul harus tersusun secara sistematis yang mencakup: 1) Tujuan yang harus dicapai, yakni dirumuskan dalam bentuk prilaku khusus sehingga dapat diukur keberhasilan siswa; 2) Petunjuk penggunaan yaitu acuan peserta didik untuk belajar menggunakan modul; 3) Kegiatan belajar, di dalamnya memuat materi yang harus dipelajari peserta didik; 4) Rangkuman materi, yakni pointpoint penting yang berkaitan dengan materi pelajaran; 5) Tugas dan latihan; 6) Sumber bacaan, yaitu buku-buku bacaan yang harus dipelajari untuk menambah dan memperdalam pengetahuan; 7) Tes atau soal-soal yang harus dikerjakan untuk mengetahui tingkat keberhasilan peserta didik dalam penguasaan materi pelajaran; 8) Kriteria keberhasilan, yaitu tingkat keberhasilan peserta didik dalam mempelajari modul; 9) Kunci jawaban. ${ }^{9}$

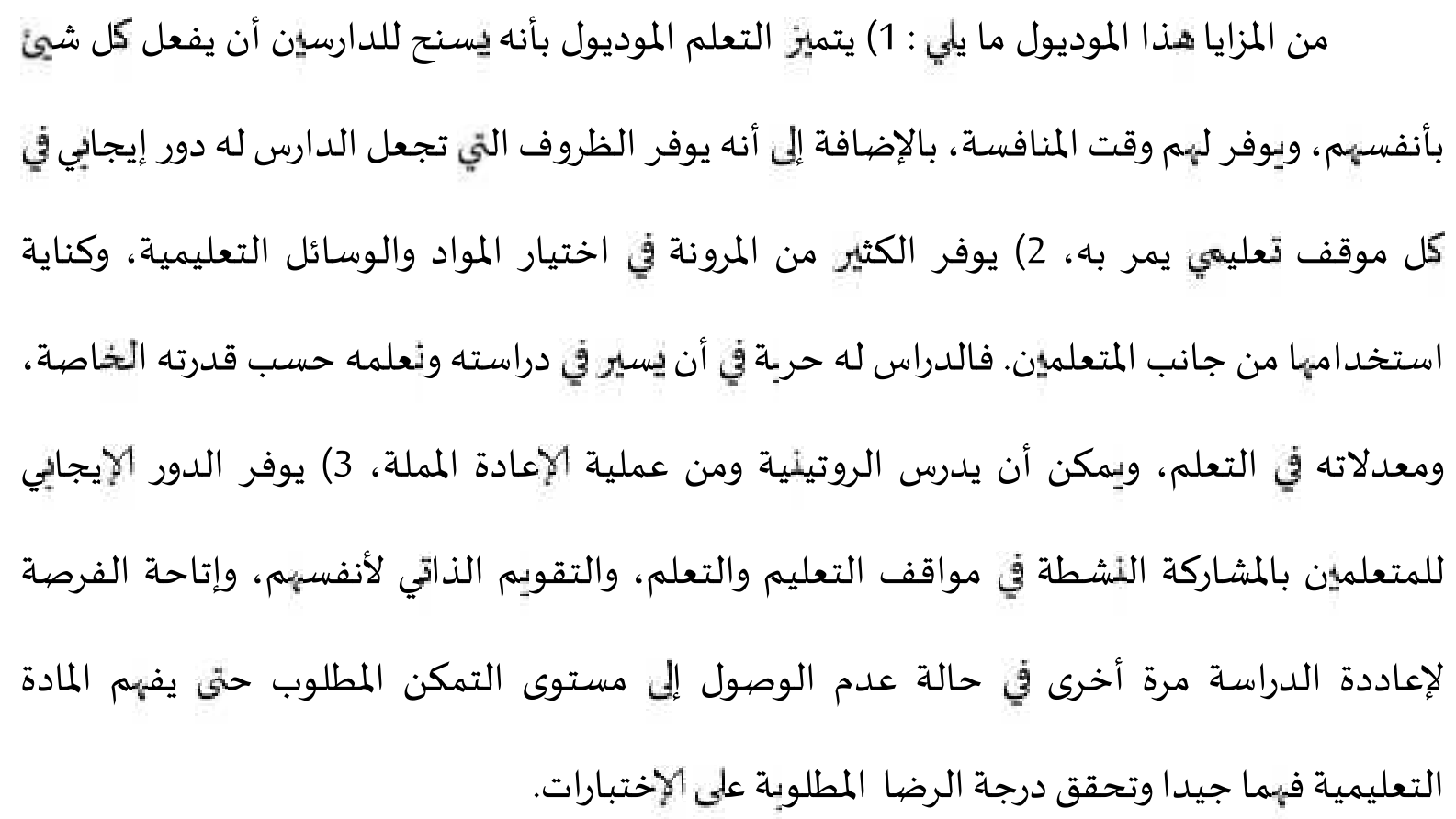

Selain memiliki kelebihan, menurut Morrison, Ross, \& Kemp yang dikutip oleh Lasmiyati, modul juga memiliki beberapa kelemahan, antara lain : (1) berkurangnya interaksi antar siswa sehingga dibutuhkan kegiatan belajar secara kelompok, (2) adanya pendekatan mandiri dapat menyebabkan siswa bosan, oleh sebab itu permasalahan yang menantang dan bervariasi sangat dibutuhkan, (3) kemandirian yang bebas menjadikan siswa malas dan mengabaikan berbagai tugas sehingga di perlukan batasan waktu untuk belajar, (4) perancangan modul harus optimal, memerlukan kerjasama tim dan dukungan parasarana, baik berupa media atau sumber lainnya, serta (5) persiapan materi menghabiskan biaya yang lebih mahal jika dibandingkan dengan penggunaan metode ceramah. ${ }^{10}$

\footnotetext{
${ }^{9}$ Wina Sanjaya, Media Komunikasi (Jakarta: Kencana Prenada Media Group, 2012). SMP."

${ }^{10}$ Lasmiyati, "Pengembangan Modul Pembelajaran Untuk Meningkatkan Pemahaman Konsep Dan Minat
} 
Secara bahasa kata Sharaf atau tasrif berarti perubahan atau pergeseran, dan secara istilah yaitu merubah bentuk asal kata kepada bentuk-bentuk lain untuk memperoleh makna yang dapat dicapai dengan adanya suatu perubahan. Menurut Azhar yang dikutip oleh Fakhrurozy, ilmu shorf merupakan ilmu yang membahas struktur kata dan keaslian huruf-hurufnya baik penambahan, penghapusan, penggantian maupun pengubahan. ${ }^{11}$ Tujuan mempelajari ilmu shorof antara lain: 1) memahami bahasa Arab, 2) memahami isi al-qur'an dan al-hadist, 3) memudahkan membaca kitab kuning atau kitab gundul yang tidak memiliki harakat. ${ }^{12}$

\section{Metode}

Penelitian yang digunakan adalah metode penelitian dan pengembangan (R\&D), yaitu penelitian yang menghasilkan produk tertentu dan menguji keefektifan produk tersebut. ${ }^{13}$ Penelitian pengembangan sebagai usaha mengembangkan dan memvalidasi produk yang digunakan pada proses pembelajaran. Pengertian yang hampir sama dikemukakan oleh Asim bahwa penelitian pengembangan dalam pembelajaran adalah proses yang digunakan untuk mengembangkan dan memvalidasi produk-produk yang digunakan dalam proses pembelajaran. ${ }^{14}$ Penelitian dan pengembangan ini mempunyai tujuan untuk menghasilkan modul sharaf pada materi fi'il mujarrad dan fi'il mazid dengan pendekatan deduktif yang nantinya bisa dimanfaatkan sebagai bahan ajar serta menguji kelayakan produk agar dapat digunakan secara efektif dan efisien. Prosedur pengembangan modul sharaf dengan pendekatan deduktif untuk meningkatkan kemampuan sharaf peserta didik menggunakan model Borg and Gall dengan pengurangan 3 tahapan terakhir sehingga tersaji tahap-tahap berikut :

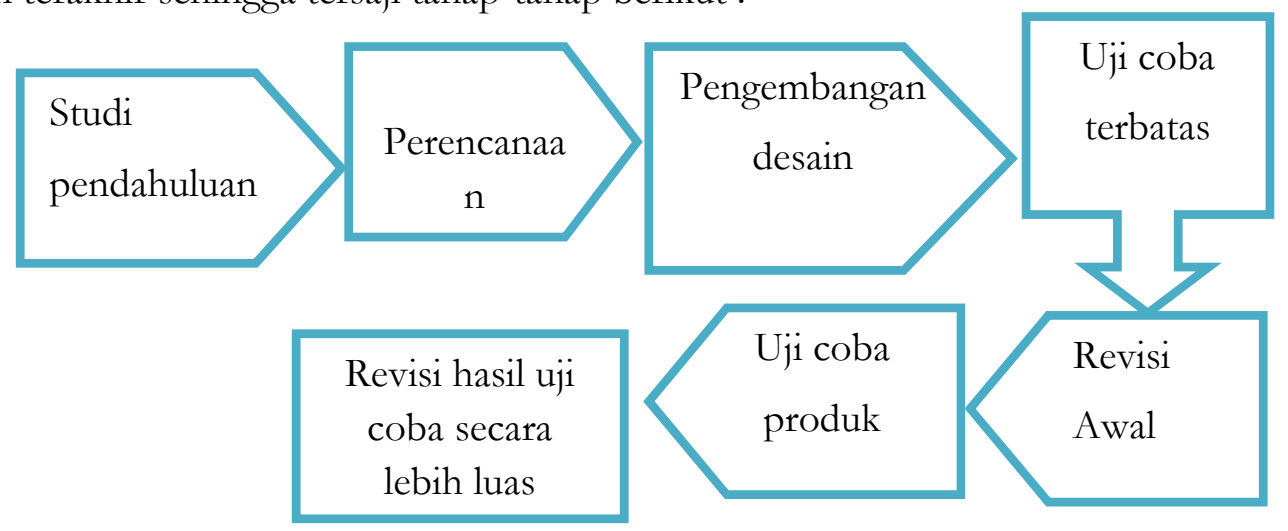

\section{Gambar 1. Tahap Penelitian dan Pengembangan Model Borg and Gall (2003)}

\footnotetext{
${ }^{11}$ M. Imam Fakhrurrozy, "Nahwu Dan Shorof Perspektif Pembelajar Bahasa Kedua," Seminar Nasioanal Bahasa Arab Mahasiswa II Tabun 2018 (2018).

12 Limas Dodi, "METODE PENGAJARAN NAHWU SHOROF (Ber-Kaca Dari Pengalaman Pesantren)," Jurnal Tafaqqub Volume 1, no. No 1 (2013).

13 Prof Dr Sugiyono, "Metode Penelitian Pendidikan," Pendekatan Kuantitatif (2010).

${ }^{14}$ Dr M Pd Asim, "Sistematika Penelitian Pengembangan" (Malang: Lembaga Penelitian-Universitas Negeri Malang, 2013).

15 Amirzan, "Pengembangan Model Pembelajaran Gerak Dasar Lokomotor Pada Siswa Sekolah Dasar Kelas V," Jurnal Tunas Bangsa Volume 5, no. Nomor 2 (n.d.): 158.
} 
Adapun tujuh tahapan yang dilakukan dalam kajian ini adalah sebagai berikut:

\section{1) Studi pendahuluan}

Studi pendahuluan yang dilakukan untuk mendapat informasi dalam penelitian dan pengembangan produk meliputi: analisis kebutuhan, riview literatur, penelitian dalam skala kecil.

\section{2) Merencanakan penelitian}

Perencanaan penelitian yang dilakukan yaitu merumuskan tujuan penelitian; memperkirakan dana, waktu dan tenaga yang akan dihabiskan; menentukan perincian produk yang akan dimuat; serta menentukan pihak yang akan terlibat dalam proses pengembangan.

\section{3) Pengembangan desain}

Modul sharaf disusun dengan menggunakan pendekatan deduktif. Kemudiaan desain produk di dalamnya semenarik mungkin menggunakan aplikasi corel $\mathrm{x} 7$ dan photoshop CC 2015 dengan memuat materi fi'il mujarrod dan fi'il mazid yang mengacu pada Standar kompetensi (SK) dan kompetensi dasar (KD). Selain materi, modul juga memuat soal latihan dan evaluasi Sumatif dengan tujuan memudahkan peserta didik belajar mandiri tanpa bimbingan guru.

\section{4) Uji coba terbatas}

Tahap ini merupakan uji produk secara terbatas dengan melakukan uji lapangan awal terhadap desain produk, bersifat terbatas terhadap substansi desain maupun pihak-pihak yang terlibat. Uji lapangan dilakukan untuk memperoleh masukan dan respon terhadap produk yang dikembangkan. Uji coba ini dilakukan oleh ahli materi dan ahli desain, masing-masing divalidasi oleh dua validator.

\section{5) Revisi Awal}

Langkah ini merupakan perbaikan desain berdasarkan uji lapangan terbatas. Setelah diketahui kelemahan dan kekurangan dari produk tersebut, maka perlu dilakukan penyempurnaan. Penyempurnaan ini lebih mengarah pada kelayakan isi produk, berdasarkan masukan atau tanggapan dari para validator.

6) Uji coba produk secara lebih luas

Setelah penyempurnaan produk pada tahap sebelumnya, dilakukan uji coba produk dengan melibatkan pihak yang lebih luas dari uji coba terbatas. Pada tahap ini dilakukan uji coba kelompok besar dan keompok kecil dengan tujuan untuk mengetahui kelayakan produk meliputi substansi dan metodologi. 


\section{7) Revisi hasil uji coba secara lebih luas}

Revisi hasil uji ini merupakan perbaikan kedua setelah dilakukan uji lapangan pendahulu. Penyempurnaan produk dari hasil uji lapangan lebih luas akan lebih menguatkan produk yang dikembangkan. Produk yang sudah dinyatakan layak bisa digunakan peserta didik secara mandiri dalam proses pembelajaran baik di luar maupun di dalam kelas.

Untuk mengetahui kelayakan modul, maka digunakan rumus sebagai berikut :

$$
\mathrm{P}_{\mathrm{s}}=\frac{\mathrm{s}}{\mathrm{N}} \times 100 \%
$$

$$
\begin{aligned}
& \text { Keterangan: } \\
& \mathrm{P}_{\mathrm{s}}=\text { Persentase } \\
& \mathrm{S}=\text { Jumlah jawaban responden dalam } 1 \text { item } \\
& \mathrm{N}=\text { Jumlah nilai ideal dalam item }{ }^{16}
\end{aligned}
$$

Sedangkan untuk mengetahui efektifitas penggunaan modul yang telah dikembangkan, maka data akan di analisis dengan menggunakan uji-t paired sampel t-test melalui aplikasi statistik SPSS 24.

\section{Hasil dan Pembahasan}

Pada penelitian ini dihasilkan bahan ajar berupa modul sharaf pada materi fi'il mujarrod dan fi'il mazid yang di desain dengan menggunakan pendekatan deduktif dan hasil yang diperoleh menunjukan kriteria sangat layak untuk digunakan. Pengembangan modul Sharaf dengan pendekatan deduktif menggunakan model Borg and Gall yang terdiri dari 10 tahapan, dengan pengurangan 3 tahapan terakhir sehingga tersaji tahap-tahap berikut:

Studi pendahuluan, yaitu tahap dimana penulis memperoleh informasi dalam penelitian dan pengembangan produk melalui teknik observasi di Pondok Modern Madinah Labuhan Maringgai Lampung Timur, kemudian melakukan wawancara tertulis kepada guru sharaf Pondok Modern Madinah Labuhan Maringgai Lampung Timur, dan juga memberikan angket kebutuhan kepada peserta didik kelas X. Hasil yang diperoleh yaitu: buku ajar yang digunakan selama ini tidak memungkinkan siswa belajar secara mandiri, (b) Materi yang disajikan dalam buku cetak tersebut kurang sistematis dan tidak banyak memuat contoh-contoh kalimat pada setiap bab serta latihan-latihan tidak sesuai dengan tujuan pembelajaran, karena Kitab tersebut tidak memuat tujuan pembelajaran yang akan dicapai oleh peserta didik. (c) rendahnya kemampuan sharaf, seperti peserta didik kurang mampu membuat contoh-contoh kalimat yang di dalamnya terdapat

\footnotetext{
${ }^{16}$ Winarni-, Pengembangan Modul Berbasis Inkuiri Terbimbing Pada Pokok Bahasan Kalor Untuk Sma/Ma Kelas X (Sebelas Maret University, 2014).
} 
fi'il mujarrod dan fi'il mazid dengan baik dan benar. Dari hasil yang diperoleh menunjukkan adanya potensi untuk mengembangkan modul yang lebih menarik dan efesien untuk membantu dan mempermudah peserta didik dalam memahami materi pelajaran.

Tahap selanjutnya perencanaan, yaitu penulis merencanakan penelitian mengenai Pengembangan modul sharaf dengan pendekatan deduktif pada materi fi'il mujarrod dan fi'il mazid seperti memperkirakan waktu, dana dan tenaga yang akan dihabiskan, rincian produk yang akan dimuat, serta menentukan pihak yang akan terlibat. Tahap selanjutnya yaitu desain produk. Setelah mengetahui permasalahan di lapangan dan mengumpulkan data yang berhubungan dengan penelitian, maka didapatkan informasi tentang pengembangan produk modul sharaf dengan pendekatan deduktif yang akan dikembangkan. Pengembangan desain ini menghasilkan produk awal. Bahan ajar yang ada sebelumnya dikembangkan lagi menjadi modul dengan pendekatan deduktif, didalamnya disajikan beberapa materi dan contoh kalimat beserta latihanlatihan yang disesuaikan dengan tujuan pembelajaran.

Tahap selanjutnya yaitu validasi produk oleh beberapa ahli, diantaranya validator ahli materi dan ahli desain, masing-masing ahli terdiri dari dua validator. Validasi dilakukan guna mengumpulkan informasi, saran dan masukan mengenai produk untuk dijadikan bahan perbaikan agar produk yang dikembangkan layak untuk digunakan sebagai modul sharaf. Pada produk awal didapatkan hasil validasi ahli materi $77 \%$, validasi ahli desain mendapat penilaian sebesar $76 \%$ dengan kriteria layak.

Setelah melakukan validasi dengan beberapa validator, langkah selanjutnya yaitu revisi produk. Saran dan masukan yang di dapat dari beberapa validator pada saat melakukan validasi, dijadikan acuan untuk melakukan revisi atau perbaikan produk yang dikembangkan. Ahli materi memberikan saran diantaranya penambahan ma'ani wazan pada contoh kalimat materi fi'il mazid, pemberian mufrodat pada setiap akhir materi setelah bagian tadrib dan penambahan kotak pada bagian tadrib 4. Ahli desain memberikan saran diantaranya merubah desain cover depan agar disesuikan dengan isi modul, menyesuaikan desain cover belakang dengan cover depan serta penambahan pada deskripsi modul dan perbaikan pada skema-skema, jenis huruf Arab, dan juga penebalan ukuran font Arab. Setelah tahap revisi modul yang dikembangkan, kemudian penulis memberi angket penilaian kembali pada validator, skor penilaian ahli materi yang sebelumnya $77 \%$ menjadi $89 \%$, skor penilaian ahli desain yang sebelumnya $76 \%$ menjadi $83 \%$ dengan kriteria sangat layak.

Tahap berikutnya yaitu uji coba produk secara luas. Uji coba produk secara luas ini dibagi menjadi dua kali uji coba, yaitu uji coba skala kecil dan uji coba skala luas. Uji coba skala kecil berjumlah 10 orang peserta didik kelas X Pondok Modern Madinah. Hasil yang diperoleh pada uji skala kecil yaitu mendapat penilaian sebesar 86\% dengan kriteria sangat layak. Selanjutnya uji 
coba secara luas, dilakukan oleh satu guru sharaf dan peserta didik kelas X sebanyak 20 orang. Hasil ujicoba ini dilakukan untuk mendapatkan penilaian, saran dan masukan mengenai produk yang dikembangkan untuk dijadikan sebagai bahan acuan perbaikan/revisi produk agar menjadi lebih baik dan lebih berkualitas. Hasil penilaian dari guru sharaf yaitu $86 \%$ dan hasil penilaian dari 20 peserta didik yaitu 89\% dengan kriteria sangat layak. Berdasarkan hasil perhitungan dengan menggunakan aplikasi SPSS 24, diketahui bahwa nilai t hitung 15,288 dan t tabel 1,69913 dengan taraf signifikan 5\%. Maka dapat disimpulkan bahwa t hitung 15,288 $\geq$ dari t tabel 1,69913 adanya perbedaan antara nilai pretest dan postest peserta didik kelas X karena Ha diterima dan Ho ditolak

Tahap yang terakhir yaitu revisi kedua dari produk yang dikembangkan atas dasar saran dan masukan dari guru sharaf Pondok Modern Madinah Labuhan Maringgai Lampung Timur yaitu: Setiap tadribat diberi harakat dan makna serta penambahan kosa kata pada setiap tashrif lughowi dan tasrif istilahi. Kemudian saran dan masukan dari peserta didik Pondok Modern Madinah Labuhan Maringgai Lampung Timur diantaranya yaitu: menambahkan cakupan materi selain fi'il mujarrod dan fïl mazid dalam modul, akan tetapi, masukan ini tidak dapat dijadikan sebagai bahan revisi karena keterbatasan peneliti dalam mengembangkan produk.

Modul sharaf dengan pendekatan deduktif ini memiliki berbagai manfaat yang lebih baik dibandingkan dengan modul lain, peserta didikmerasa mudah dalam mempelajari materi karena masing-masing peserta didik dapat mempelajari materi secara langsung dan mandiri tanpa bantuan atau kehadiran seorang guru. Modul ini ini bersifat fleksibel karena mudah digunakan kapan saja dilengkapi dengan materi pembelajaran yang sudah disesuaikan dengan SK KD, terdapat banyak contoh kalimat dengan makna wazan dan latihan-latihan yang disesuaikan dengan tujuan pembelajaran serta memuat kosa kata di setiap akhir materi.

\section{Kesimpulan}

Pengembangan modul sharaf dengan pendekatan deduktif sangat layak untuk digunakan dalam pembelajaran sharaf di Pondok Modern Madinah Labuhan Maringgai Lampung Timur. Hal ini dibuktikan dengan hasil validasi oleh tim ahli yang mendapatkan hasil penilaian dengan kriteria sangat baik. Hasil validasi ahli materi yaitu $89 \%$ dan hasil validasi ahli desain pembelajaran yaitu $86 \%$. Hasil uji coba skala kecil diperoleh persentase kelayakan sebesar $86 \%$, uji coba skala luas diperoleh persentase kelayakan sebesar 89\% dan uji coba guru sharaf yaitu 86\%. Modul Sharaf dengan pendekatan deduktif terbukti efektif dalam meningkatkan kemampuan qowa'id sharaf peserta didik, dibuktikan dengan hasil perhitungan uji paired sample t test menggunakan aplikasi SPSS 24. Nilai rata-rata pre test peserta didik yaitu 54,16 dan nilai post test 84,16 . Hasil perhitungan melalui aplikasi SPSS 24, diketahui bahwa nilai $t_{0}=15,288$ dan $t_{\text {tabel }}$ 1,69913 pada 
36 | Volume 11, Nomor 1, Juni 2020

taraf sifnifikan 5\%. Maka dapat disimpulkan bahwa $t_{0} 15,288>t_{\text {tabel }}$ 1,69913. Adanya perbedaan antara nilai pretest dan postest peserta didik kelas X, karena Ha diterima dan Ho ditolak.

\section{Daftar Pustaka}

Ahmad Saiful Mujab. "Pengembangan Modul Bahasa Arab Berbasis Teori Psikologi

Perkembangan Remaja Elizabeth B. Hurlock Kelas X MA.” Jurnal Lisanul Arab Vol 7, no.

No 1 (2018): 33-37.

Amirzan. "Pengembangan Model Pembelajaran Gerak Dasar Lokomotor Pada Siswa Sekolah

Dasar Kelas V." Jurnal Tunas Bangsa Volume 5, no. Nomor 2 (n.d.): 158.

Asim, Dr M Pd. “Sistematika Penelitian Pengembangan.” Malang: Lembaga Penelitian-

Universitas Negeri Malang, 2013.

Fakhrurrozy, M. Imam. "Nahwu Dan Shorof Perspektif Pembelajar Bahasa Kedua.” Seminar

Nasioanal Bahasa Arab Mahasiswa II Tahun 2018 (2018).

Isnainiyah. "Pengembangan Kitab Matan Al-Jurumiyah Dengan Pendekatan Induktif Untuk Siswi

Madrasah Diniyah Nurul Ulum.” Seminar Nasional Bahasa Arab Mahasiswa III (2019): 1-20.

Lasmiyati, Idris Harta. "Pengembangan Modul Pembelajaran Untuk Meningkatkan Pemahaman

Konsep Dan Minat SMP.” Pythagoras: Jurnal pendidikan Matematika Vol 9, no. No 2 (2014):

$161-174$.

Limas Dodi. "METODE PENGAJARAN NAHWU SHOROF (Ber-Kaca Dari Pengalaman

Pesantren)." Jurnal Tafaqqub Volume 1, no. No 1 (2013).

Majid, Abdul. "Perencanaan Pembelajaran.” Bandung: PT Remaja Rosdakarya (2008).

Nasional, Departemen. "Pendidikan, Panduan Pengembangan Bahan Ajar.” Direktorat

Pembinaan Sekolah Menengah Atas: Direktorat Jenderal Manajemen ..., 2008.

Prastowo, Andi. “Panduan Kreatif Membuat Bahan Ajar Inovatif.” Yogyakarta: DIVA press, 2011.

Septyenthi, Sica, Aprizal Lukman, and Upik Yelianti. "Pengembangan Modul Pembelajaran IPA

Berbasis Entrepreneurship Di SMK Negeri 2 Kota Jambi." Edu-Sains: Jurnal Pendidikan

Matematika dan Ilmu Pengetabuan Alam 3, no. 2 (2014).

Sica Septyenthi, Aprizal Lukman, Upik Yelianti. "Pengambangan Modul Pembelajaran IPA

Berbasis Entrepreneurship Di SMK Negeri 2 Kota Jambi.” Jurnal Edu Sains Vol 3, no. No 2 (2014).

Sugiyono, Prof Dr. "Metode Penelitian Pendidikan.” Pendekatan Kuantitatif (2010).

Wina Sanjaya. Media Komunikasi. Jakarta: Kencana Prenada Media Group, 2012.

Winarni-. Pengembangan Modul Berbasis Inkuiri Terbimbing Pada Pokok Babasan Kalor Untuk Sma/Ma

Kelas X. Sebelas Maret University, 2014. 